\title{
Linkage of epidermolysis bullosa simplex to keratin gene loci
}

\author{
K E McKenna, A E Hughes, E A Bingham, N C Nevin
}

Department of Dermatology, Royal Victoria Hospital, Grosvenor Road, Belfast BT12 6BA Northern Ireland. K E McKenna E A Bingham

Department of Medical Genetics, The Queen's University Belfast, Belfast City Hospital, Belfast, Northern Ireland. A E Hughes N C Nevin

Correspondence to Dr McKenna.

Received 28 January 1992 Accepted 13 February 1992

\begin{abstract}
Epidermolysis bullosa simplex (EBS) is an autosomal dominant disorder characterised by intraepidermal blistering of the skin. Two families with Weber-Cockayne EBS have been analysed for linkage to keratin gene loci. In the first family, linkage was found to chromosome 17 markers flanking the keratin 14 gene (D17S74: $\mathrm{Zmax}=+2 \cdot 45, \theta=0 \cdot 10$; COL1A1: $\mathrm{Zmax}=+0.97, \theta=0.00)$ and markers near the keratin 5 gene on chromosome 12 were excluded (D12S17: $Z<-2 \cdot 0, \theta=0 \cdot 08$; COL2A1: $Z<-2 \cdot 0, \theta=0 \cdot 13)$. In contrast, the second family showed linkage to the region containing the keratin 5 gene (D12S17: $\mathrm{Zmax}=+1 \cdot 37, \theta=0 \cdot 08 ;$ COL2A1: $\mathrm{Zmax}=+0.33, \theta=0.15)$ and was not linked to the keratin 14 gene (D17S74: $Z<-2 \cdot 0$, $\theta=0 \cdot 14)$. The Weber-Cockayne form of EBS is genetically hetergeneous with linkage to different keratin gene loci.
\end{abstract}

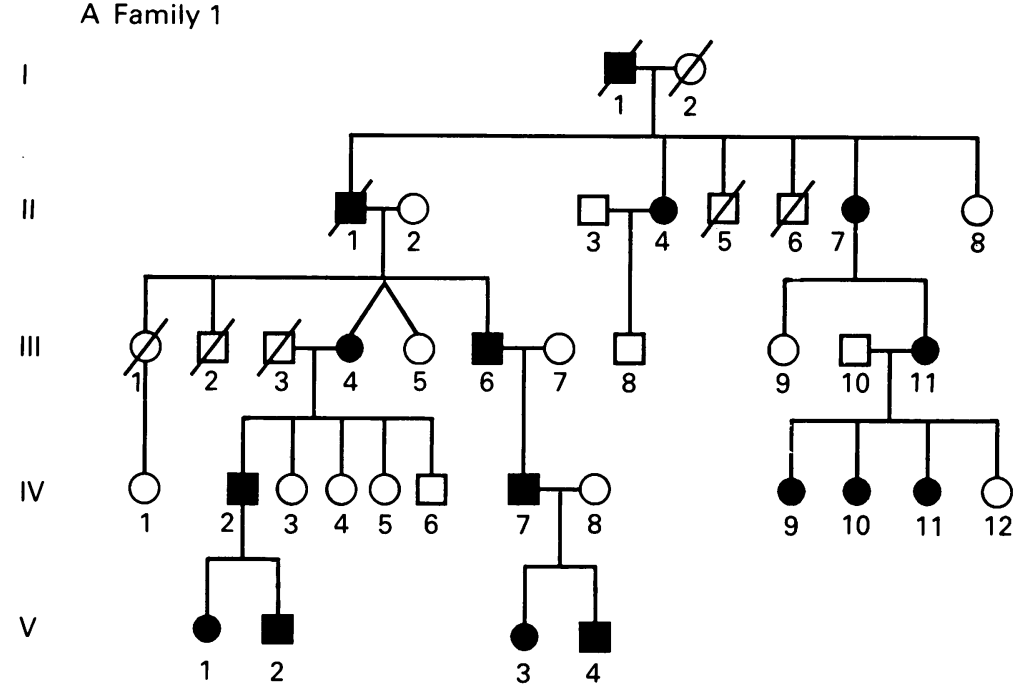

B Family 2

I

III

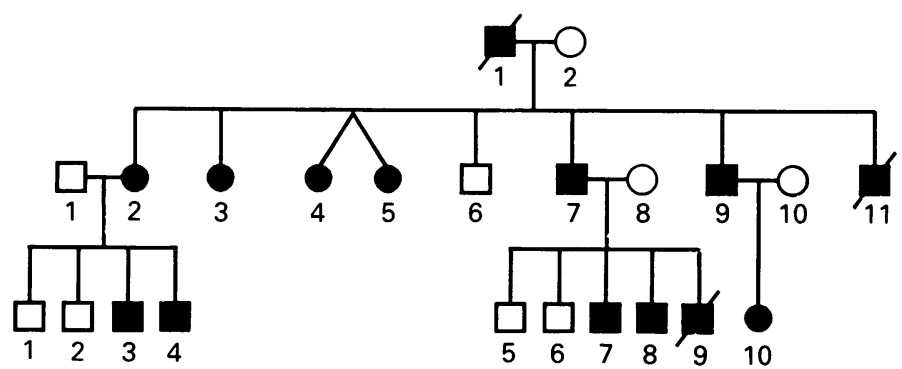

Epidermolysis bullosa simplex (EBS) is a nonscarring blistering disorder of the skin, characterised by autosomal dominant inheritance. ${ }^{12}$ Blister cleavage is intraepidermal with basal cell cytolysis. The most common forms of EBS present as blistering either localised to the hands and feet (Weber-Cockayne or EBSWC) or with more generalised blistering (Koebner or EBS-K). Abnormal epidermal keratin filament formation with associated basal cell cytolysis has recently been found in transgenic mice expressing a mutant keratin 14 gene. ${ }^{3}$ This suggests the importance of keratin filaments in maintaining epidermal cytoskeletal stability. Abnormal organisation of keratin intermediate filaments in patients with EBS has also been recognised ${ }^{4-6}$ and clumping of keratin tonofilaments in the Dowling-Meara form of EBS (EBS-DM) is a characteristic feature.

These findings prompted us to study whether two families with EBS-WC showed linkage to the keratin gene clusters on chromosomes 12 and 17. Previous authors ${ }^{89}$ have also suggested that EBS-WC and EBS-K are linked to chromosome 1 loci. We studied one of our families to determine whether their disease was linked to these loci.

\section{Patients and methods}

PATIENTS

Family 1 (fig 1A) consists of four living generations with 14 affected members who complain of recurrent blistering of the hands and feet. The blistering mainly affects the feet and is more common during the summer months. The onset of blistering varied from 3 months to 7 years. In this family there is no mucosal blistering or dental or nail involvement. Family 2 (fig 1B) comprises three living generations with 11 affected subjects. Their blistering is confined to the soles of the feet. Onset of blistering was in infancy. There is no other manifestation of the disorder. Electron microscopic examination of skin from affected members of each family confirmed the presence of epidermal basal cell cytolysis. Blood samples were obtained from affected and unaffected members of each family. Genomic DNA was extracted from these samples and Duffy status was established by blood group analysis in family 1.

SOUTHERN HYBRIDISATION

DNA was digested with several restriction enzymes and electrophoresed through $1 \%$

Figure 1 Pedigrees of EBS-WC families $1(A)$ and $2(B)$. 
agarose gels at $65 \mathrm{~V}$ overnight. After electrophoresis, DNA fragments were depurinated, denatured, and transferred to nylon membranes (Hybond $\mathrm{N}+$, Amersham International). DNA probe hybridisation and autoradiography were used to identify polymorphisms as listed in table 1 .

Table 1 Polymorphisms on chromosomes 1, 12, and 17 analysed by Southern blotting.

\begin{tabular}{|c|c|c|c|c|}
\hline Chromosome & Locus & Probe & Enzyme & Alleles (kb) \\
\hline $\begin{array}{l}1 \mathrm{q} 21-\mathrm{q} 23 \\
1 \mathrm{q} 21 \\
1 \mathrm{q}\end{array}$ & $\begin{array}{l}M U C 1 \\
\text { SPTA1 } \\
D 1 S 42\end{array}$ & $\begin{array}{l}\text { pMUC7 } \\
3021 E 1 \\
\text { L1054 }\end{array}$ & $\begin{array}{l}\text { HinfI } \\
\text { MspI } \\
M s p \mathrm{I}\end{array}$ & \multirow{2}{*}{$\begin{array}{l}\text { VNTR } 2 \cdot 5-7 \cdot 0 \\
\text { A1 } 16 \cdot 2, \text { A2 } 10 \cdot 0,6 \cdot 2 \\
\text { A1 } 9 \cdot 3, \text { A2 } 6 \cdot 8, \\
\text { A3 } 4 \cdot 7,3 \cdot 9, \text { A4 } 4 \cdot 7 \\
\text { A1 } 4 \cdot 0, \text { A2 } 3 \cdot 2, \text { A3 } 2 \cdot 6 \\
\text { VNTR } 1 \cdot 0-3 \cdot 5\end{array}$} \\
\hline $\begin{array}{l}12 \mathrm{q} 13-24.1 \\
17 \mathrm{q}\end{array}$ & $\begin{array}{l}D 12 S 17 \\
D 17 S 74\end{array}$ & $\begin{array}{l}\text { pYNH15 } \\
\text { pCMM86 }\end{array}$ & $\begin{array}{l}M s p \mathrm{I} \\
\text { HinfI }\end{array}$ & \\
\hline
\end{tabular}

Table 2 Polymorphisms on chromosomes 1, 12, and 17 analysed by PCR.

\begin{tabular}{lll}
\hline Locus & Map location & Alleles (bp) \\
\hline$A T 3$ & $1 \mathrm{q} 23$ & $272 \& 198$ \\
$A T 3$ & $1 \mathrm{q} 23$ & $270 \& 188+82$ \\
$(P s t \mathrm{I})$ & & $127 \& 53+74$ \\
$A T 3$ & $1 \mathrm{q} 23$ & \\
$(D d e \mathrm{I})$ & & (CA)n 131-145 \\
$A P O A 2$ & $1 \mathrm{q} 21-\mathrm{q} 23$ & VNTR 600-720 \\
$C O L 2 A 1$ & $12 \mathrm{q} 13.1-\mathrm{q} 14.3$ & $1000 \& 800+200$ \\
$\begin{array}{c}C O L 1 A 1 \\
(\text { RsaI })\end{array}$ & $17 \mathrm{q} 21.3-\mathrm{q} 22.15$ & \\
\hline
\end{tabular}

Table 3 Pairwise lod scores between EBS and chromosome 1q, 12q, and 17q loci.

\begin{tabular}{|c|c|c|c|c|c|c|}
\hline \multirow[b]{2}{*}{ Locus } & \multicolumn{5}{|c|}{ Lod score at $\theta$ of } & \multirow[b]{2}{*}{$\mathrm{Zmax} / \theta$} \\
\hline & 0.01 & 0.05 & $0 \cdot 1$ & $0 \cdot 2$ & 0.3 & \\
\hline $\begin{array}{l}\text { Family } 1 \\
\text { MUC1 } \\
\text { SPTA1 } \\
\text { Fy } \\
A P O A 2 \\
A T 3 \\
D 12 S 17 \\
C O L 2 A 1 \\
D 17 S 74 \\
\text { COL1A1 }\end{array}$ & $\begin{array}{l}-6.21 \\
-2.73 \\
+1.01 \\
-6.22 \\
-5.84 \\
-5.53 \\
-6.52 \\
+1.22 \\
+0.95\end{array}$ & $\begin{array}{l}-2.88 \\
-1.36 \\
+1.00 \\
-2.92 \\
-3.11 \\
-2.90 \\
-3.73 \\
+2.29 \\
+0.87\end{array}$ & $\begin{array}{l}-1.58 \\
-0.80 \\
+0.96 \\
-1.65 \\
-2.11 \\
-1.88 \\
-2.55 \\
+2.45 \\
+0.77\end{array}$ & $\begin{array}{l}-0.51 \\
-0.35 \\
+0.80 \\
-0.57 \\
-1.10 \\
-0.99 \\
-1.41 \\
+2.10 \\
+0.56\end{array}$ & $\begin{array}{l}-0.10 \\
-0.15 \\
+0.59 \\
-0.12 \\
-0.52 \\
-0.53 \\
-0.76 \\
+1.40 \\
+0.36\end{array}$ & $\begin{array}{c}\overline{\overline{\bar{T}}} \\
+1.01 / 0.01 \\
\overline{-} \\
\overline{\bar{z}} \\
+2 . \overline{45} / 0 \cdot 10 \\
+0.97 / 0.00\end{array}$ \\
\hline $\begin{array}{l}\text { Family } 2 \\
\text { D12S17 } \\
\text { COL2A1 } \\
\text { D17S74 }\end{array}$ & $\begin{array}{l}+0.75 \\
-0.52 \\
-8.72\end{array}$ & $\begin{array}{l}+1.27 \\
+0.09 \\
-4.60\end{array}$ & $\begin{array}{l}+1.34 \\
+0.28 \\
-2.92\end{array}$ & $\begin{array}{l}+1.15 \\
+0.32 \\
-1.37\end{array}$ & $\begin{array}{l}+0.82 \\
+0.22 \\
-0.60\end{array}$ & $\begin{array}{c}+1.37 / 0.08 \\
+0.33 / 0.15 \\
-\end{array}$ \\
\hline
\end{tabular}
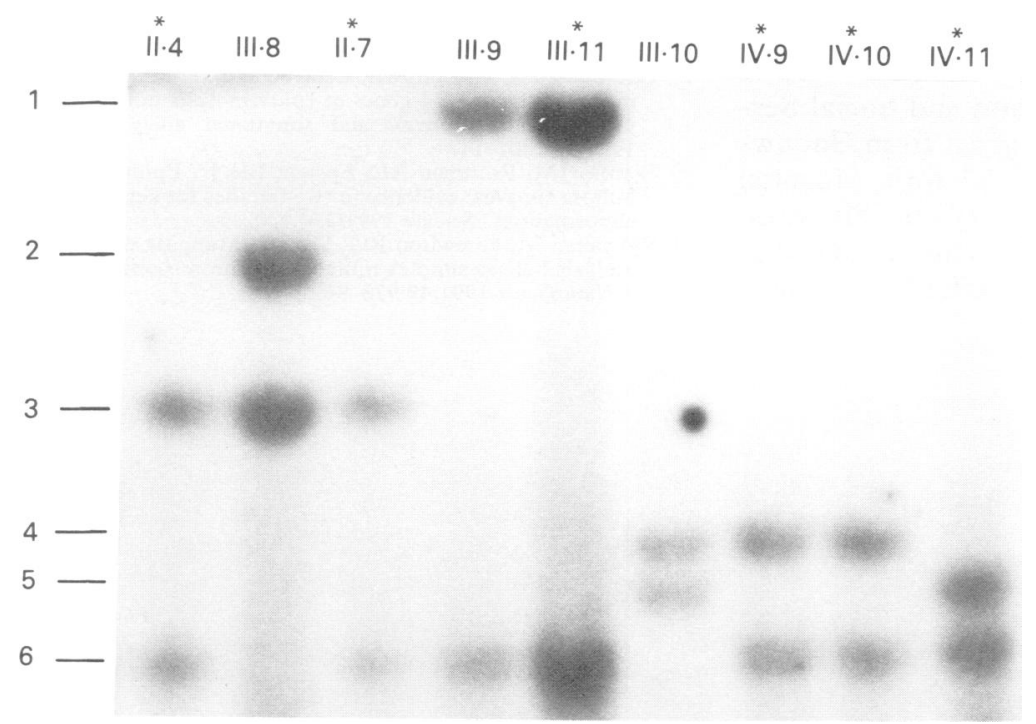

Figure 2 Southern blot of HinfI digests of DNA from part of family 1 probed with pCMM86 (D17S74). Subjects are numbered above each lane as in fig $1 \mathrm{~A}$ and those affected are marked with an asterisk. Alleles are labelled 1 to 6 . The disease gene is transmitted with allele number 6 . Subject III.9 is a recombinant.

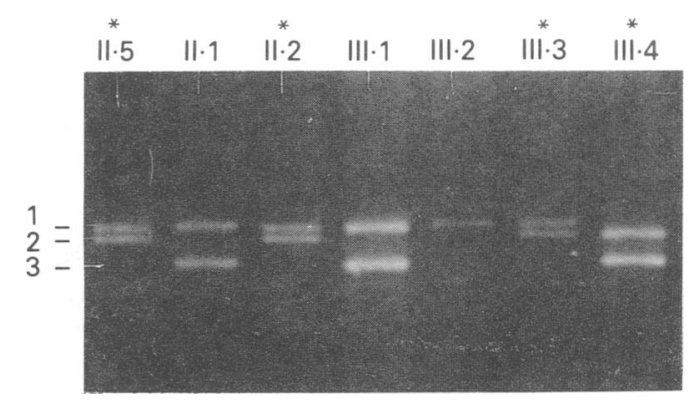

Figure 3 PCR amplification of COL2A1 polymorphisms in part of family 2. Subjects are numbered above each lane as in fig $1 B$ and those affected are marked with an asterisk. Alleles are labelled 1 to 3. The disease gene is transmitted with allele number 2.

POLYMERASE CHAIN REACTION (PCR)

PCR was used to analyse polymorphisms at the $A T 3, A P 0 A 2, C O L 2 A 1$, and $C O L 1 A 1$ loci (table 2). PCR was performed on a thermocycler (Techne) using Taq polymerase (Cambio) according to conditions described by previous authors. ${ }^{9-13}$ PCR products were analysed by gel electrophoresis with previous enzyme digestion when necessary.

\section{DATA ANALYSIS}

Linkage analyses were carried out using the LINKAGE computer program, version 5.04. ${ }^{14}$

\section{Results}

Polymorphisms on chromosomes 12 and 17 were analysed in both families and also on chromosome 1 in family 1 (table 3 ). Linkage to markers flanking the region containing the keratin 14 gene (chromosome 17q12-q21) was found in family 1 . The D17S74 locus was analysed using the probe pCMM86 (fig 2) giving a maximum lod score ( $\mathrm{Zmax}$ ) of +2.45 at recombination fraction $(\theta)=0 \cdot 10$ and the less informative COL1A1 locus by PCR $(Z \max =+0.97, \theta=0.00)$. Multilocus analysis gave a $\mathrm{Zmax}$ of 3.6 at the $C O L 1 A 1$ locus. Exclusion of linkage to markers flanking the region containing the keratin 5 gene (12q11q13) was found in this family (D12S17: $\mathrm{Z}<-2 \cdot 0, \quad \theta=0.08 ; \quad \operatorname{COL} 2 A 1: \quad \mathrm{Z}<-2 \cdot 0$, $\theta=0 \cdot 13$ ). In contrast, family 2 was not linked to the D17S74 locus $(Z<-2 \cdot 0, \theta=0 \cdot 14)$ but showed probable linkage to the D12S17 locus using the probe pYNH15 (Zmax $=+1 \cdot 37$, $\theta=0.08)$. PCR analysis of the COL $2 A 1$ locus (fig 3) gave a $\mathrm{Zmax}=+0.33$ at $\theta=0 \cdot 15$. These data provide evidence that in these families $E B S-W C$ is linked to different keratin gene loci on chromosomes 12 and 17.

Family 1 was studied for possible linkage to chromosome 1 markers. Analysis of haplotypes of three polymorphisms within the AT3 gene excluded close linkage to this locus $(\mathrm{Z}<-2 \cdot 0, \theta=0 \cdot 10)$. Possible linkage between the EBS-WC gene and Fy is indicated; however, this can be discounted on the basis of exclusion from the more informative $A P 0 A 2$ locus $(Z \max =-2.0$ at $\theta=0.075)$ which maps very close to the $F y$ locus. Multilocus analysis 
(data not shown) indicates that the gene causing EBS-WC in family 1 does not lie in the $M U C 1-A T 3$ region of chromosome 1q, thus excluding the $E B S 2^{9}$ locus.

\section{Discussion}

Keratins are major structural proteins of the epidermis and form an extensive network of intermediate filaments. Keratins can be divided into two different classes, type 1 and type $2 .{ }^{15}$ One member of each type is required for intermediate filament formation. In the basal cells of the epidermis the type 1 keratin $\mathrm{K} 14$ and the type 2 keratin $\mathrm{K} 5$ are expressed. ${ }^{16}$ These basal cell keratins are encoded by keratin gene clusters on chromosomes 17 and 12 respectively. ${ }^{1718}$

There is now considerable evidence to implicate the keratin genes in the pathogenesis of EBS. In all forms of EBS cytolysis occurs in the basal layer of the epidermis and there is abnormal keratin intermediate filament formation. ${ }^{4-7}$ Transgenic mice expressing a mutant $\mathrm{K} 14$ gene also develop these features of the disease. ${ }^{3}$ Different point mutations have been found within the $\mathrm{K} 14$ gene in two patients with EBS-DM ${ }^{19}$ and a third point mutation in this gene has also been identified in a family with EBS-K. ${ }^{20}$ Recently, a family with EBS which was initially generalised and subsequently mainly localised to the hands and feet has shown linkage to loci near the $\mathrm{K} 5$ gene. ${ }^{21}$ One family with EBS-WC is also reported to be linked to this region. ${ }^{20}$

We have found one family with EBS-WC affecting the hands and feet linked to the keratin 14 gene on chromosome 17 . This is the first report of a family with EBS-WC showing linkage to this locus. Our second family with disease confined to the feet shows probable linkage to the region of the keratin 5 gene on chromosome 12 . We hope to elucidate the nature of the mutations responsible for the disease in these two families.

This work was supported by a grant from the dystrophic epidermolysis bullosa research association (DEBRA). Dr K E McKenna is grateful to the Eastern Health and Social Services Board for a research grant from Endowment Funds of the Royal Victoria Hospital which has enabled him to carry out this work. We thank the Collagen Genetics Group, Oxford, for supplying COL1Al primers (funded by the EC Concerted Action on Heritable Connective Tissue Disease) and the Human Genome Mapping Project (HGMP), London for supplying probes pYNH15 and 3021E1 (donated by Drs Y Nakamura, $R$ White, and B Forget). The authors thank Dr Kevin Ennis for helpful advice.

1 Gedde-Dahl T Jr. Sixteen types of epidermolysis bullosa: on the clinical discrimination, therapy and prenatal diaon this. Acta Dermatol Venereol (Suppl) 1981;95:74-87.

2 Fine JD, Bauer EA, Briggaman RA, et al. Revised clinical and laboratory criteria for subtypes of inherited epidermolysis bullosa: a consensus report by the Subcommittee on Diagnosis and Classification of the National Epideron Diagnosis and Classification of the National Epidermolysis Bullosa

3 Vassar R, Coulombe PA, Degenstein L, et al. Mutant keratin expression in transgenic mice causes marked abnormalities resembling a human genetic skin disease. Cell 1991;64:365-80.

4 Haneke E, Anton-Lamprecht I. Ultrastructure of blister formation in epidermolysis bullosa hereditaria. V. Epidermolysis bullosa simplex localisata type Weber-Cockayne. F Invest Dermatol 1982;78:219-23.

5 Kitajima Y, Inoue S, Yaoita H. Abnormal organization of keratin intermediate filaments in cultured keratinocytes of epidermolysis bullosa simplex. Arch Dermatol Res 1989;281:5-10.

6 Ito M, Okuda C, Shimizu N, et al. Epidermolysis bullosa simplex (Koebner) is a keratin disorder. Ultrastructural and immunohis

7 Anton-Lamprecht I, Schyder UW. Epidermolysis bullosa herpetiformis Dowling-Meara: report of a case and pathomorphogenesis. Dermatologica 1982;164:221-35.

8 Mulley JC, Nicholls CM, Propert DN, et al. Genetic linkage analysis of epidermolysis bullosa simplex, Koebner type. Am 7 Hum Genet 1984;19:573-7.

9 Humphries MM, Sheils D, Lawler M, et al. Epidermolysis bullosa: evidence for linkage to genetic markers on chromosome 1 in a family with the autosomal dominant simplex form. Genomics 1990;7:377-81.

10 Daly ME, Perry DJ. DdeI polymorphism in intron 5 of the ATIII gene. Nucleic Acids Res 1990;18:5583.

11 Weber JL, May PE. Abundant class of human DNA polymorphisms which can be typed using the polymerase polymorphisms which can be typed using the polym

12 Wu S, Seino S, Bell GI. Human collagen, type II, alpha 1 , (COL2A1) gene: VNTR polymorphism detected by gene (COL2A1) gene: VNTR polymorphism detected

13 Baker R, Lynch J, Ferguson L, et al. PCR detection of five restriction site dimorphisms at the type I collagen loci COL1A1 and COL1A2. Nucleic Acids Res 1991;19:4315.

14 Lathrop GM, Lalouel JM, Julier C, Ott J. Strategies for multilocus linkage analysis in humans. Proc Natl Acad Sci USA 1984;81:3443-6.

15 Fuchs E, Coppock SM, Green H, Cleveland DW. Two distinct classes of keratin genes and their evolutionary significance. Cell 1981;27:75-84.

16 Nelson $W$, Sun TT. The 50- and 58-kdalton keratin classes as molecular markers for stratified squamous epithelia: as molecular markers for stratified squamous

17 Rosenberg M, Raychaudhury A, Shows TB, et al. A group of type 1 keratin genes on human chromosome 17: characof type 1 keratin genes on human chromosome 17: charac-

18 Rosenberg M, Fuchs E, Lebeau MM, et al. Three epidermal and one epithelial keratin gene map to human chromal and one epithelial keratin gene map

19 Coulombe PA, Hutton ME, Letai A, et al. Point mutations in human keratin 14 genes of epidermolysis bullosa simplex patients: genetic and functional analyses. Cell 1991;66:1301-11.

20 Bonifas JM, Rothman AL, Epstein EH Jr. Epidermolysis bullosa simplex: evidence in two families for keratin gene abnormalities. Science 1991;254:1202-5.

21 Ryynanen M, Knowlton RG, Uitto J. Mapping of epidermolysis bullosa simplex mutation to chromosome 12. Am f Hum Genet 1991;49:978-84. 